\title{
Synthesis of New Conjugated Mesomeric Betaines from Alkoxycarbonylazinium Salts
}

\section{Jesús Valenciano ${ }^{a}$, Ana M. Cuadro", Juan. J. Vaquero a, José L. García-Navío, Julio Alvarez-Builla ${ }^{a *}$, Pilar Gómez-Sal ${ }^{b}$ and Avelino Martín}

a'Departamento de Quimica Orgánica and bepartamento de Quimica Inorgánica, Universidad de Alcalá. 28871-Alcalá de Henares. Madrid. Spain.

\begin{abstract}
A new series of conjugated mesomeric betaines have been synthesized from the reaction of various aminoheterocycles with 2 -methylthio-4-oxo-3-phenylpyrido| $2,1-f][1,2,4]$ triazinium iodide, itself prepared from 2-ethoxycarbonylpyridinium $\mathrm{N}$-aminide. Some of the heterobetaines and salts obtained have been studied by ${ }^{1} \mathrm{H}$-NMR, and their structures have been confirmed by X-ray analysis. The crystal structures reveal unexpected complementary stabilizing interactions between some betaines and their salts Copyright (C) 1996 Published by Elsevier Science Ltd
\end{abstract}

\section{INTRODUCTION}

Heterocyclic mesomeric betaines ${ }^{1}$ have been the subject of extensive investigation, mainly because of their 1,3-dipolar character (1), which allows them to take part in 1,3-dipolar cycloadditions with various dipolarophiles, thus generating novel five-membered aza heterocycles. ${ }^{2}$ As 1,4-dinucleophiles (2), heterobetaines can react with 1,2-dicarbonyl compounds ${ }^{3}$ to give a variety of azonia derivatives possessing a quaternary bridgehead nitrogen. However, apart from a few examples in the literature which describe the reactivity of 2 carbonylpyridinium $\mathrm{N}$-aminides with nitriles, and the dimerization of 2-cyano-, 2-alkoxy carbonyl-and 2-aroyl-Naminoazinium salts ${ }^{4}$, little is known about their behavior as 1,4-nucleophile-electrophiles (3) (Figure 1).

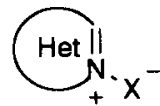

$\mathrm{X}=\mathrm{NH}, \mathrm{CHR}$
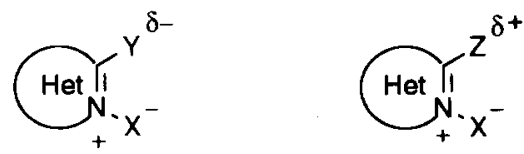
In an earlier paper we reported an example of this 1,4-nucleophilic-electrophilic character of 2alkoxycarbonylazinium- $\mathrm{N}$-ylides and $\mathrm{N}$-aminides, ${ }^{\mathrm{S}_{\mathrm{a}}}$ which on reaction with heterocumulenes in a $[4+2]$ cyclocondensation process gave rise to new conjugated mesomeric betaines $\mathbf{5}$ containing the system pyrido[2,1$f][1,2,4]$ triazinium $^{5 b}$. These $\mathrm{N}$-ylides however, also behave as 1,3-dipoles when reacted with DMAD to afford the corresponding cycloadducts 4 (Scheme 1 ).

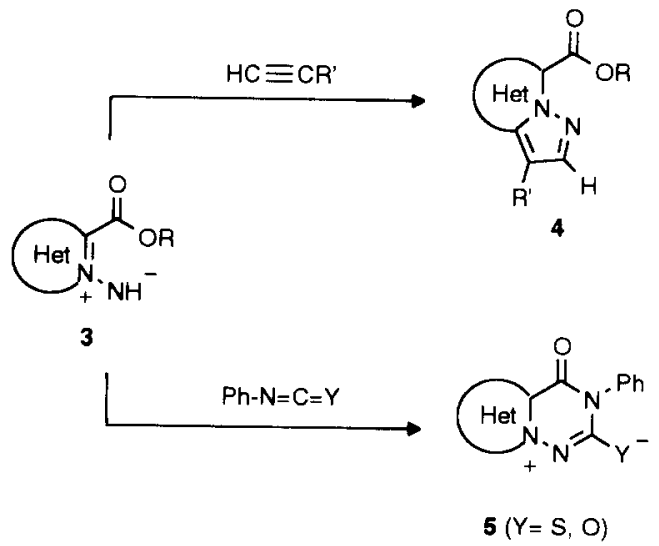

Scheme 1

As an extension of this preliminary work, we wish to report here the transformation of heterobetaines 5 into a new class of conjugated mesomeric betaines whose structure has been studied by $\mathrm{X}$-ray diffraction.

\section{RESULTS AND DISCUSSION}

The azinium $\mathrm{N}$-aminides ${ }^{6} 3$, which were readily generated from 2 -alkoxycarbonylazinium salts, reacted with phenyl isocyanate and isothiocyanate affording the corresponding heterobetaines 5 in good yields. Subsequent S-methylation of the 4-oxo-3-phenylpyrido[2,1-f][1,2,4]triazinium-2-thiolate 5a afforded the corresponding salt 6 (Scheme 2). The displacement of the methylthio group ${ }^{7}$ by various heterocycles was examined with an eye towards generating new heterobetaines where the negative charge would be extensively delocalized over the attached heterocyclic moiety. Thus, 6 was reacted with 2-aminothiazole, 2aminobenzothiazole, and 2-amino-1,3,4-thiadiazole in the presence of $\mathrm{K}_{2} \mathrm{CO}_{3} / \mathrm{CH}_{3} \mathrm{CN}$ to give the expected mesomeric conjugated betaines $7 \mathrm{a}-\mathrm{c}$ in good yields. However, when 6 was reacted with the hydrate of 2aminotetrazole under the same conditions, it was extensively transformed into the corresponding 4-oxo-3phenylpyrido $[2,1-f][1,2,4]$ triazinium-2-olate 5b. When anhydrous 2-aminotetrazole was used, unreacted 6 was recovered with none of the desired betaine being observed, even after prolonged refluxing. After several unsuccessful attempts $\left(\mathrm{Et}_{3} \mathrm{~N} / \mathrm{EtOH}, \mathrm{K}_{2} \mathrm{CO}_{3} / \mathrm{CH}_{2} \mathrm{Cl}_{2}, \mathrm{Et}_{3} \mathrm{~N} / \mathrm{DMF}\right.$ ), the heterobetaine 7d could be formed (26\%) in the presence of diisopropylethylamine (Hunig's base), after $48 \mathrm{~h}$ reflux, with an appreciable amount of 6 also being recovered. The use of a large excess of 2-aminotetrazole seemed to moderately improve the yield of $7 \mathrm{~d}$, as interpreted from the ${ }^{1} \mathrm{H}$ NMR analysis of the crude mixture. However, the difficulty associated with the work-up of the reaction mixture led to a similar low yield of the isolated compound (Scheme 2). 


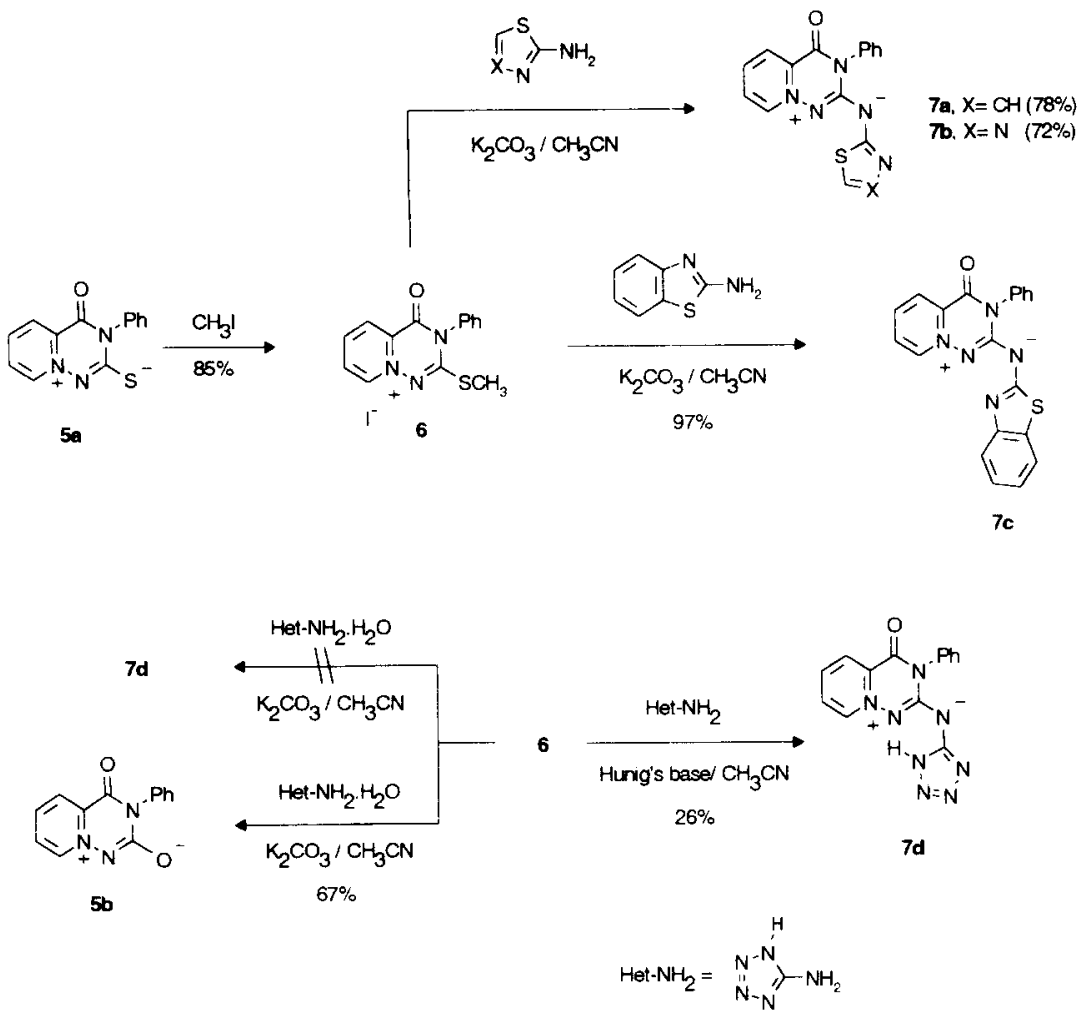

Scheme 2

When the nucleophilic displacement of the methylthio group in 6 was attempted using 2aminobenzimidazole, different reaction products were found depending on the conditions used (Scheme 3 ). Thus, in the absence of base the 2-(benzimidazole-2-ylidenamino-4-oxo-3-phenylpyrido[2,1-f]-[1,2,4]triazinium iodide $8 \mathrm{a}$ was isolated in $83 \%$ yield, which upon treatment with $\mathrm{K}_{2} \mathrm{CO}_{3}$ was transformed into the mesomeric conjugated betaine $7 \mathrm{f}$. However, when the reaction of 6 with 2 -aminobenzimidazole was performed in the presence of base $\left(\mathrm{K}_{2} \mathrm{CO}_{3} / \mathrm{CH}_{3} \mathrm{CN}\right)$, the betaine $7 \mathrm{e}$ was obtained, which was rapidly converted into $7 \mathrm{f}$ in the presence of protic solvents such as ethanol, or slowly in aprotic polar solvents such as DMSO or acetonitrile. Additionally, salt 8 a could be obtained by treating $7 f$ with $57 \%$ hydriodic acid in methanol

The structures of $\mathbf{8 a}$ and $\mathbf{7 f}$ were initially assigned on the basis of their characteristic 'H-NMR data. Compounds $7 \mathbf{e}$ an $7 \mathbf{f}$ exhibit somewhat different ${ }^{1} \mathrm{H}$-NMR spectra. The chemical shifts of the protons assigned to the pyridinium moiety of $7 \mathbf{f}$ show four well-resolved signals starting at $\delta=9.27 \mathrm{ppm}$. The benzo-protons of the benzimidazole display an asymmetrical pattern, and the NH proton appears as a singlet at $\delta=11.44 \mathrm{ppm}$. Compound $7 \mathbf{e}$ however, shows relatively high field signals with the most shielded proton of the pyridinium moiety appearing at $\delta=8.43 \mathrm{ppm}$. The aromatic ring protons of benzimidazole resonate as AA'BB' multiplets, and the NH proton shows up at $\delta=12.6 \mathrm{ppm}$. Finally, compound 8a presents two equivalent NH protons at $\delta=12.46 \mathrm{ppm}$ and an overlapping of the signals corresponding to benzimidazolyl and pyridyl ring protons. 


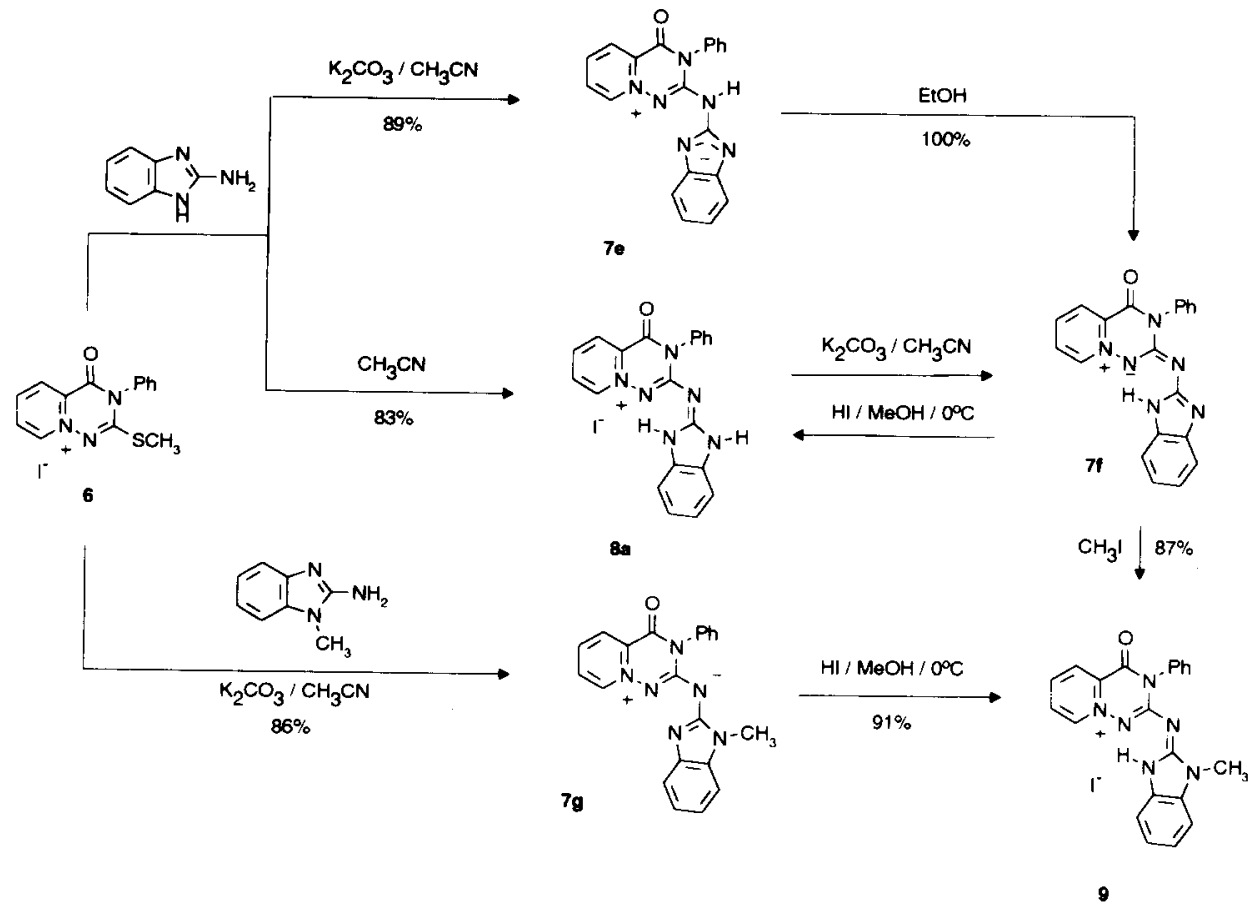

Scheme 3

Methylation of $7 \mathbf{f}$ with methyl iodide gave the salt $\mathbf{9}$, which could alternatively be obtained in a two-step transformation by reacting 6 with 2-amino-1-methylbenzimidazole, followed by treatment with hydriodic acid in methanol. These conversions provide further support for the structures assigned to $7 \mathbf{f}$ and $\mathbf{8 a}$, which were finally confirmed by $X$-ray analysis. Figures 2 and 3 represent the structures of $7 \mathbf{f}$ and $\mathbf{8 a}$, and give the corresponding labelling scheme, while Figures 4 and 5 show the unit cells for both compounds. and show some of the more relevant intermolecular interactions.

The molecular structures of compounds $7 \mathbf{f}$ and $8 \mathrm{a}$ are very similar. Figures 2 and 3 show that both the betaine $7 \mathbf{f}$ and the salt $8 \mathbf{a}$ are virtually planar, the angle between the main plane of the benzimidazole ring and the main plane of the pyrido[2,1-f]triazinium system being $8.1(2)^{\circ}$ in $7 \mathbf{f}$, and $3.7(4)^{\circ}$ in 8 . The phenyl group is twisted in both compounds, $98.2(2)^{\circ}$ in $7 \mathrm{f}$ and $61.4(6)^{\circ}$ in $8 \mathrm{a}$.

In the betaine $7 \mathrm{f}$, the distances from the exocyclic nitrogen to the contiguous carbon atoms are slightly different, $(\mathrm{N}(4)-\mathrm{C}(2)=1.31(1) \AA$ and $\mathrm{N}(4)-\mathrm{C}(8)=1.37(1) \AA)$, showing some preference for the location of the double bond between $\mathrm{N}(4)$ and $\mathrm{C}(2)$. The other distances confirm extensive delocalization within the structure, with all the $\mathrm{C}-\mathrm{N}$ distances being very similar. A comparable situation exists for $\mathbf{8 a}$, and an analysis of the distances does not allow us to locate any multiple bond. $\mathrm{X}$-ray analyses confirm intramolecular hydrogen bonds in both compounds $7 \mathrm{f}(\mathrm{N}(5)-\mathrm{N}(2)=2.63(1) \AA)$ and $8 \mathrm{a}(\mathrm{N}(3)-\mathrm{N}(5)=2.70(2) \AA)$. 


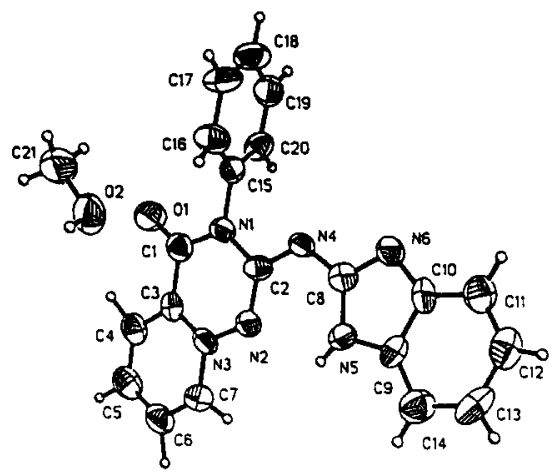

7f

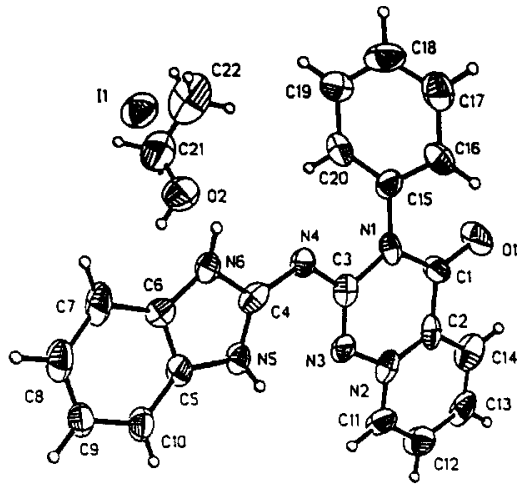

$8 a$

Figures 2 and 3. ORTEP drawing of compounds $7 \mathrm{f}$ and $8 \mathrm{a}$ with atomic numbering scheme

Compounds $7 \mathbf{f}$ an $8 a$ crystallize in a triclinic crystal system, in which one molecule of methanol and ethanol are incorporated respectively. Figure 4 shows the unit cell of $7 f$ and the intermolecular hydrogen bonding interaction between $\mathrm{N}(6)$ of the benzimidazole ring and the oxygen atom of the solvent $(\mathrm{N}(6)$ $O(2)=2.78(1) \AA$ ). Figure 5 shows a similar effect in 8a, although the interaction is weaker $(N(6)-O(2)=3.02(2) \AA)$.

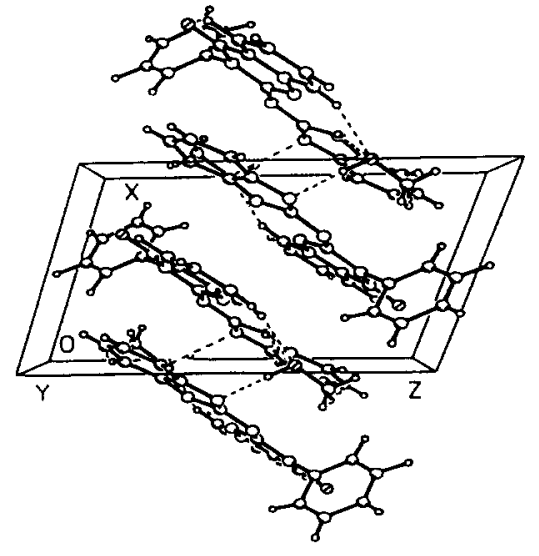

$7 f$

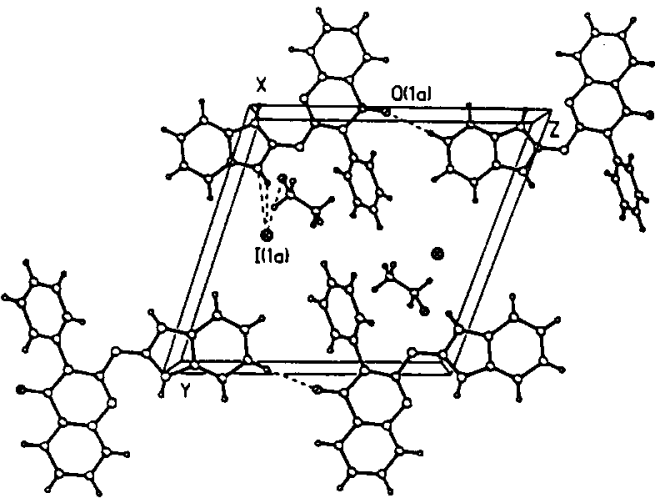

$8 \mathbf{a}$

Figures 4 and 5. Unit cell packing of compounds $7 \mathbf{f}$ and $8 \mathbf{a}$ showing relevant intermolecular interactions. 
Surprisingly, when 2-aminoimidazole was reacted with 6 the precipitate obtained was not the expected heterobetaine $7 \mathrm{~h}$ but the structure 10, in which the betaine is strongly associated to its corresponding salt through a hydrogen bond between two imidazole nitrogens (Scheme 4)

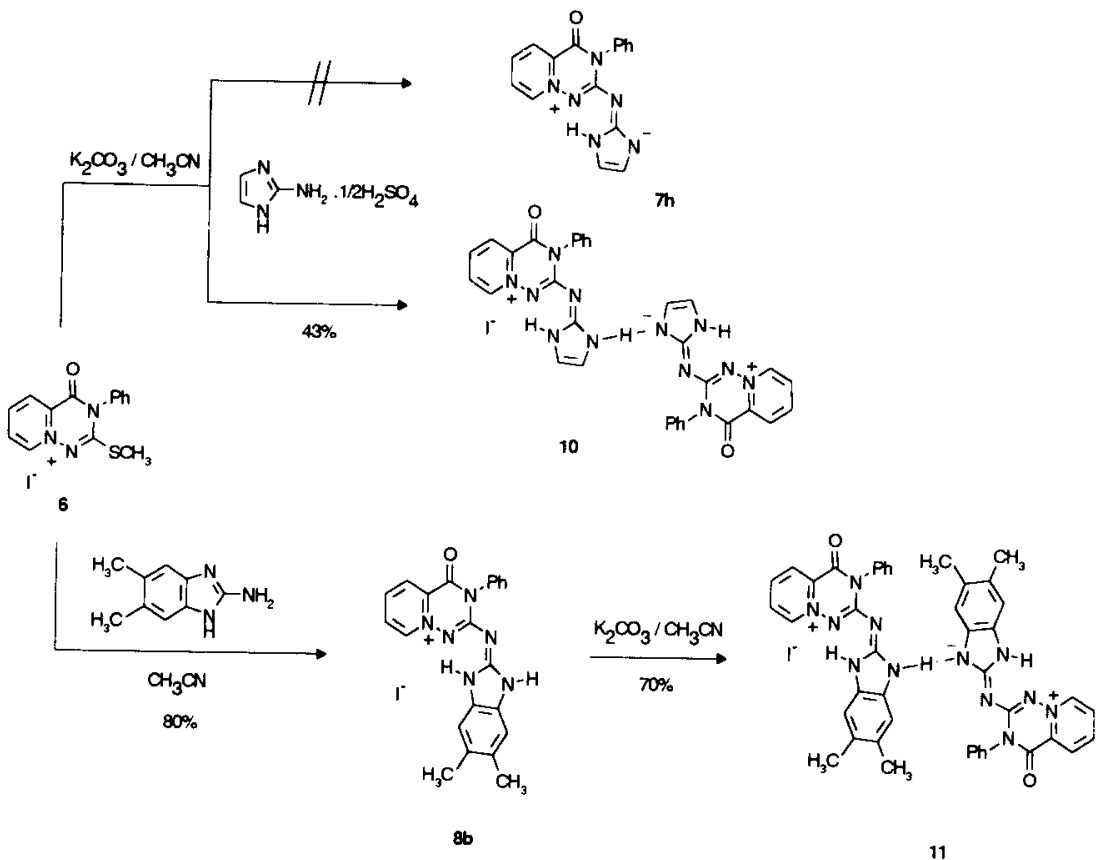

Scheme 4

Although the ${ }^{1} \mathrm{H}$ NMR of the compound presented some of the characteristics associated with the heterobetaines 7. microanalysis strongly suggested it to have a "dimeric" structure and the presence of a single iodide ion. $\mathrm{X}$-ray analysis confirmed the proposed structure, whose three-dimensional view and unit cell packing in are shown in Figure 6 and 7 respectively.

Figure 6 gives a perspective view of 10. From this the "dimeric" structure arranged around a proton, which is situated at the center of a hydrogen bond in a symmetry center between two equal molecules, is evident. Consequently, there is one iodide counterion for each dimer. This ion shows some crystallographic disorder and we have found two different positions for it with occupancies of $90 \%$ and $10 \%$.

The "dimeric" structure is virtually planar, with an angle between the main plane of the imidazole ring and the main plane of the pyrido[2,1-f]triazinium system of $15.2(2)^{\circ}$ and $11.6(2)^{\circ}$ in each half of the structure, and thus shows some loss of planarity with respect to compounds $7 \mathbf{f}$ and $\mathbf{8 a}$. The phenyl group is twisted $106.4(2)^{\circ}$ and $90.7(2)^{\circ}$ from the plane of the bicyclic system in each molecule. These small differences between both molecules are probably due to the crystalline packing, as no significant differences are apparent in the bond distances. As was observed in $7 \mathbf{f}$ and $\mathbf{8 a}$, the $X$-ray analysis showed intramolecular interactions $N(12)-N(16)$ $(2.635(5) \AA)$ and $\mathrm{N}(1)-\mathrm{N}(6)(2.716(9) \AA)$

The crystal and experimental details of the structure determination of compounds $7 \mathbf{f}, \mathbf{8 a}$ and 10 are presented in Table 1 . 
Table 1. Crystal data and structure refinement for $7 \mathrm{f}, \mathbf{8 a}$ and $\mathbf{1 0}$

\begin{tabular}{|c|c|c|c|}
\hline & $7 f$ & $8 \mathbf{a}$ & 10 \\
\hline Empirical formula & $\mathrm{C}_{20} \mathrm{H}_{14} \mathrm{~N}_{6} \mathrm{O} \cdot \mathrm{CH}_{3} \mathrm{OH}$ & $\mathrm{C}_{20} \mathrm{H}_{15} \mathrm{IN}_{6} \mathrm{O} \cdot \mathrm{C}_{2} \mathrm{H}_{5} \mathrm{OH}$ & $\mathrm{C}_{32} \mathrm{H}_{26} \mathrm{IN}_{12} \mathrm{O}_{2} \cdot \mathrm{CH}_{3} \mathrm{CN}$ \\
\hline Molecular weight & 386.41 & 528.34 & 762.59 \\
\hline Temperature (K) & \multicolumn{3}{|c|}{$293(2)$} \\
\hline Wavelength ( $\boldsymbol{\AA})$ & \multicolumn{3}{|c|}{0.71073} \\
\hline Crystal system & Triclinic & Triclinic & Triclinic \\
\hline Space group & $P-1$ & $P-1$ & $P-1$ \\
\hline$a(A) a\left({ }^{0}\right)$ & $8.567(3) .85 .52(5)$ & $6.889(5), 108.31(5)$ & $8.175(2) .101 .44(3)$ \\
\hline$b(\AA), b\left(^{\prime \prime}\right)$ & $10.074(7) .73 .25(4)$ & $12.964(7), 94.08(5)$ & $11.647(2), 91.41(3)$ \\
\hline$c(\AA), g\left({ }^{\circ}\right)$ & $12.461(8), 65.73(4)$ & $13.156(6), 104.55(5)$ & $18.281(4) .97 .40(3)$ \\
\hline $\operatorname{Volume}\left(\AA^{3}\right)$ & $937.8(9)$ & $1065(1)$ & $1689.6(6)$ \\
\hline z & 2 & 2 & 2 \\
\hline$D_{\text {calc }}\left(\mathrm{gcm}^{-3}\right)$ & 1.368 & 1.644 & 1.530 \\
\hline $\begin{array}{l}\text { Absorption coefficient } \\
\left(\mathrm{mm}^{-1}\right)\end{array}$ & 0.093 & 1.515 & 1.001 \\
\hline$F(000)$ & 404 & 527 & 786 \\
\hline Crystal size $(\mathrm{mm})$ & $0.25 \times 0.20 \times 0.20$ & $0.25 \times 0.20 \times 0.15$ & $0.40 \times 0.36 \times 0.28$ \\
\hline$\theta$ range for data collection & 2 to $27^{\circ}$ & 2 to $27^{\circ}$ & 2.60 to $24.77^{\circ}$ \\
\hline Index ranges & $\begin{array}{l}-10<\mathrm{H}<10 . \\
-12<\mathrm{K}<12,0<\mathrm{L}<15\end{array}$ & $\begin{array}{l}-8<\mathrm{H}<8 . \\
-15<\mathrm{K}<15 .,-(0<\mathrm{L}<15\end{array}$ & $\begin{array}{l}0<\mathrm{H}<9 \\
-13<\mathrm{K}<13,-2 \mathrm{I}<\mathrm{L}<21\end{array}$ \\
\hline Reflections collected & 4338 & 4003 & 6261 \\
\hline Independent reflections & 4099 & 3834 & 5734 \\
\hline Refinement method & \multicolumn{3}{|c|}{ Full matrix least-squares on $F^{2}$} \\
\hline Data/restraints/parameters & $4077 / 0 / 308$ & $3826 / 0 / 284$ & $5725 / 0 / 456$ \\
\hline Goodness-of-fit on $\mathrm{F}^{2}$ & 1.102 & 1.126 & 1.084 \\
\hline Final $R$ indices, reflections & $\begin{array}{l}\mathrm{R} I=0.093 \\
\mathrm{wR} 2=0.136(1129)\end{array}$ & $\begin{array}{l}\mathrm{R} 1=0.125 \\
\mathrm{wR} 2=0.344(2238)\end{array}$ & $\begin{array}{l}\mathrm{R} 1=0.055 \\
\mathrm{wR} 2=0.128(335 \mathrm{I})\end{array}$ \\
\hline \multicolumn{4}{|l|}{$[\mathrm{I}>2 \sigma(\mathrm{I})]$} \\
\hline $\begin{array}{l}\text { Weighting scheme } \\
\mathrm{P}=\left(\mathrm{F}_{0}{ }^{2}+2 \mathrm{~F}_{\mathrm{c}}{ }^{2}\right) / 3\end{array}$ & $\begin{array}{l}\text { calc } \\
w=1 /\left[\sigma^{2}\left(\mathrm{~F}_{\mathrm{o}}{ }^{2}\right)+(0.0003 \mathrm{P})^{2}\right. \\
+ \\
3.5654 \mathrm{P}]\end{array}$ & $\begin{array}{l}\text { calc } \\
w=1 /\left[\sigma^{2}\left(\mathrm{~F}_{o}^{2}\right)+(0.1851 \mathrm{P})^{2}\right. \\
+ \\
41.8267 \mathrm{P}]\end{array}$ & $\begin{array}{l}\text { calc } \\
w=1 /\left[\sigma^{2}\left(\mathrm{~F}_{\mathrm{o}}{ }^{2}\right)+(0.0549 \mathrm{P})^{2}\right. \\
+ \\
4.9028 \mathrm{P}]\end{array}$ \\
\hline $\begin{array}{l}\text { Largest diff. peak and hole } \\
\left(\mathrm{e} \AA^{-3}\right)\end{array}$ & 0.403 and -0.279 & 2.190 and -2.693 & 1.060 and -0.647 \\
\hline
\end{tabular}



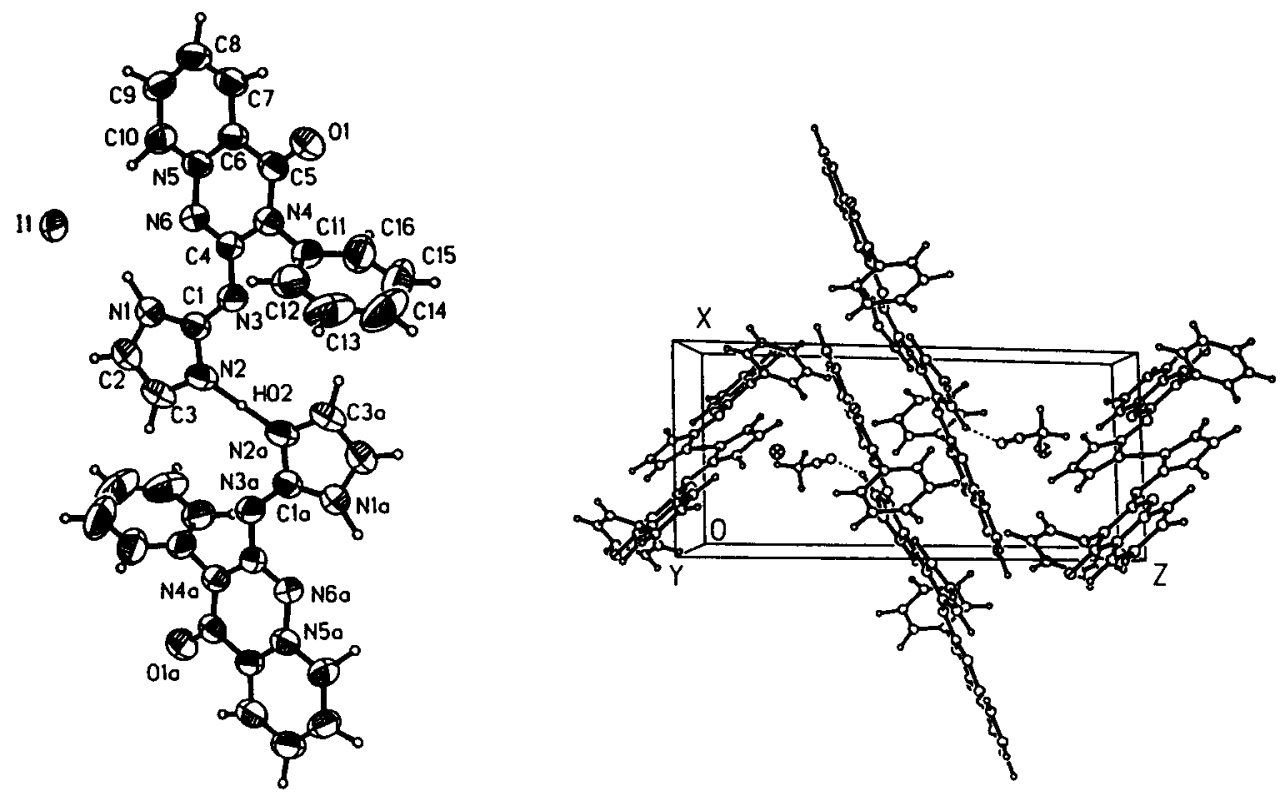

10

Figures 6 and 7. ORTEP drawing and unit cell packing of compound $\mathbf{1 0 .}$

A similar structure to 10 was obtained in the reaction of $\mathbf{6}$ with 2-amino-5,6-dimethylbenzimidazole, as shown in Scheme 4. Treatment of 6 with an excess of the aminoheterocycle in acetonitrile at room temperature resulted in the formation of the salt $8 \mathbf{b}(80 \%)$ which, when treated with $\mathrm{K}_{2} \mathrm{CO}_{3}$ yieided a precipitate that was identified as 11. The ${ }^{1} \mathrm{H}$ NMR spectrum of compound 10 shows a singlet corresponding to the $\mathrm{C} 3$ and $\mathrm{C} 4$ imidazole protons at $\delta=6.82 \mathrm{ppm}$, thus indicating a symmetrical structure. This symmetry is also evident in compound 11 where both methyl substituents resonate as a singlet at $\delta=2.22 \mathrm{ppm}$. Generally speaking, it can be said that all those compounds possessing both acidic hydrogens and electron-rich nitrogens should easily associate through intra or intermolecular hydrogen bonds, depending on the solvent and the $\mathrm{pH}$ of the medium, with the generation of a more stable crystalline structure being the driving force.

In conclusion, the nucleophilic displacement of the methylthio group in 2-methylthio-4-oxo-3phenylpyrido[2,1-f][1,2,4]triazinium iodide by aminoheterocycles allowed the straightforward synthesis of various mesomeric conjugated heterocyclic betaines. Small variations in the nature of the aminoheterocycle were seen to lead to unexpected molecular associations arising from strong hydrogen bonding interactions. 


\section{EXPERIMENTAL SECTION}

Melting points were determined on an Electrothermal IA6304 apparatus. Infrared spectra were recorded on a Perkin-Elmer 1310 spectrophotometer using KBr pellets. 'H NMR spectra were recorded on a Varian Unity 300 instrument. Mass spectra were determined on a Hewlett-Packard 5988A (70 eV) spectrometer. X-ray calculations were performed on an ALPHA AXP (Digital) Workstation. Column chromatography was performed on silica gel, SDS (0.035-0.070 mm). 4-Oxo-3-phenylpyrido[2,1-f][1,2,4]triazinium-2-thiolate (5a) and 2methylthio-4-oxo-3-phenylpyrido $[2,1-f][1,2,4]$ triazinium iodide (6) were prepared using our previously described method $^{\text {sa }_{2}}$. All other chemicals are commercially available.

General Procedure for the Preparation of 4-Oxo-3-phenylpyrido $[2,1-f \mid 1,2,4]$ triazinium-2-azolates Inner Salts (7). To a stirred suspension of 2-methylthio-4-oxo-3-phenylpyrido[2,1-f][1,2,4]triazinium iodide $6(0.40$ $\mathrm{g}, 1 \mathrm{mmol})$ and the corresponding 2 -aminoheterocycle $(1.1 \mathrm{mmol})$ in dry acetonitrile $(10 \mathrm{~mL})$, anhydrous $\mathrm{K}_{2} \mathrm{CO}_{3}$ $(0.55 \mathrm{~g}, 4 \mathrm{mmol})$ was added. The reaction mixture was stirred at room temperature for $48 \mathrm{~h}$ and the solvent was removed to dryness. The residue was then triturated with water $(3 \times 1 \mathrm{~mL})$ and the resulting precipitate was filtered. washed with water until neutral and crystallized as indicated.

7a. Following the general procedure, using 2-aminothiazole, $0.25 \mathrm{~g}(78 \%)$ of $7 \mathrm{a}$ was isolated as orange prisms: $\quad m p$ 306-307 ${ }^{\circ} \mathrm{C}$ (DMF); IR (KBr) 1685, 1530, 1446, 1401, 1245, $1188 \mathrm{~cm}^{-1},{ }^{1} \mathrm{H}$ NMR (DMSO-d $\left.d_{6}\right) \delta$ 8.84-8.81 (m, 1H), 8.38-8.35 (m, 1H), 8.05-8.01 (m, 2H), 7.54-7.50 (m, 2H), 7.47-7.43 (m, 1H), 7.33-7.30 (m, $2 \mathrm{H}), 7.23(\mathrm{~d}, 1 \mathrm{H}, J=3.7 \mathrm{~Hz}), 7.02(\mathrm{~d}, 1 \mathrm{H}, J=3.7 \mathrm{~Hz})$. Anal. Calcd for $\mathrm{C}_{16} \mathrm{H}_{11} \mathrm{~N}_{5} \mathrm{OS}: \mathrm{C}, 59.80 ; \mathrm{H}, 3.45 ; \mathrm{N}$, $21.79 ;$ S, 9.98. Found: C, 59.51; H, 3.26; N, 21.50; S, 9.69 .

7b. Following the general procedure, from 2 -aminothiadiazole, $7 \mathbf{b}$ was isolated as yellow microprisms (0.23 g, 72\%): $\mathrm{mp} 311-312^{\circ} \mathrm{C}$ (DMF); IR (KBr) 1687, 1530, 1495, 1430, 1398, 1299, 1230, $1184,1145 \mathrm{~cm}^{-1}$. ${ }^{1} \mathrm{H}$ NMR (DMSO- $\left.d_{6}\right) \delta 8.96(\mathrm{~s}, 1 \mathrm{H}), 8.90-8.87(\mathrm{~m}, 1 \mathrm{H}), 8.42-8.38(\mathrm{~m}, 1 \mathrm{H}), 8.12-8.05(\mathrm{~m}, 2 \mathrm{H}), 7.57-7.42(\mathrm{~m}$, $3 \mathrm{H})$, 7.34-7.30 (m, 2H). Anal. Calcd for $\mathrm{C}_{15} \mathrm{H}_{10} \mathrm{~N}_{6} \mathrm{OS}: \mathrm{C}, 55.89 ; \mathrm{H}, 3.13 ; \mathrm{N}, 26.07 ; \mathrm{S}, 9.95$. Found: C, 55.6I: H, 2.92; N, 25.78; S, 9.67

7c. Following the general procedure, from 2-aminobenzothiazole, work-up of the mixture gave 7c $(0.36$ g, 97\%) as orange prisms: $\mathrm{mp} 336-337^{\circ} \mathrm{C}$ (DMF); IR (KBr) 1697, 1538, 1500, 1477, 1441, $1293 \mathrm{~cm}^{-1}$; ${ }^{1} \mathrm{H}$ NMR $\left(\right.$ DMSO- $\left.d_{6}\right) \delta 8.94-8.90(\mathrm{~m}, \mathrm{lH}), 8.43-8.37(\mathrm{~m}, 1 \mathrm{H}), 8.13-8.05(\mathrm{~m}, 2 \mathrm{H}), 7.72(\mathrm{dd}, 1 \mathrm{H}, J=7.7,0.7 \mathrm{~Hz}), 7.57-$ $7.42(\mathrm{~m}, 4 \mathrm{H}), 7.37-733(\mathrm{~m}, 2 \mathrm{H}), 7.26 .7 .19(\mathrm{~m}, \mathrm{lH}), 7.11-7.05(\mathrm{~m}, 1 \mathrm{H}) ; \mathrm{MS}(\mathrm{m} / \mathrm{z}) 371\left(\mathrm{M}^{+}, 21\right), 78(100)$. Anal. Calcd for $\mathrm{C}_{20} \mathrm{H}_{13} \mathrm{~N}_{5} \mathrm{OS}: \mathrm{C}, 64.68 ; \mathrm{H}, 3.53 ; \mathrm{N}, 18.86 ; \mathrm{S}, 8.63$. Found: $\mathrm{C}, 64.54 ; \mathrm{H}, 3.25 ; \mathrm{N}, 18.58 ; \mathrm{S}, 8.39$.

7d. Diisopropylethylamine $(0.7 \mathrm{~mL}, 4 \mathrm{mmol})$ was added to a stirred suspension of $6(0.40 \mathrm{~g}, 1 \mathrm{mmol})$ and 2-aminotetrazole $(0.1 \mathrm{~g}, 1 \mathrm{mmol})$ in dry acetonitrile $(15 \mathrm{~mL})$. After $48 \mathrm{~h}$ reflux, the solvent was removed and the residue was purified by column chromatography on silica gel using acetone:methanol $(9.5: 0.5)$ as eluent. Crystallization gave $7 \mathrm{~d}(0.08 \mathrm{~g}, 26 \%)$ as yellow needles: mp 273-274 ${ }^{\circ} \mathrm{C}(\mathrm{EtOH})$; IR (KBr) $1710,1548,1517$, 1492, 1441, $1098 \mathrm{~cm}^{-1}$; ' $\mathrm{H}$ NMR (DMSO- $\left.d_{6}\right) \delta 14.50(\mathrm{~s}, 1 \mathrm{H}), 9.41(\mathrm{dd}, \mathrm{lH}, J=4.0,2.6 \mathrm{~Hz}$ ), $8.38(\mathrm{dd}, 1 \mathrm{H}, J$ $=7.7,1.8 \mathrm{~Hz}), 8.18-8.05(\mathrm{~m}, 2 \mathrm{H}), 7.55-7.41(\mathrm{~m}, 3 \mathrm{H}), 7.33-7.28(\mathrm{~m}, 2 \mathrm{H})$. Anal. Calcd for $\mathrm{C}_{14} \mathrm{H}_{10} \mathrm{~N}_{8} \mathrm{O}: \mathrm{C}, 54.90$; 
H, 3.29; N, 36.58. Found: C, 54.92; H, 3.43; N, 36.91 .

7e. This compound was prepared from $6(0.40 \mathrm{~g}, 1 \mathrm{mmol})$ and 2 -aminobenzimidazole $(0.15 \mathrm{~g}, 1.1 \mathrm{mmol})$ following the general procedure. Purification gave $0.31 \mathrm{~g}(89 \%)$ of $7 \mathrm{e}$ as dark red prisms: $\mathrm{mp} 242-243{ }^{\circ} \mathrm{C}$ (DMF); IR (KBr) 3245, 1685, 1599, 1566, 1442, 1202, $1148 \mathrm{~cm}^{-1},{ }^{1} \mathrm{H}$ NMR (DMSO- $d_{6}$ ) $\delta 12.58(\mathrm{~s}, 1 \mathrm{H}), 8.43$ (d, $1 \mathrm{H}, J=6.2 \mathrm{~Hz}), 8.23(\mathrm{dd}, 1 \mathrm{H}, J=7.7,1.8 \mathrm{~Hz}), 7.84-7.78(\mathrm{~m}, 1 \mathrm{H}), 7.76-7.69(\mathrm{~m}, 1 \mathrm{H}), 7.63-7.56(\mathrm{~m}, 2 \mathrm{H})$, 7.27-7.20 (m, 2H), 7.14-7.07 (m, 2H), 6.95-6.90 (m, 2H), 6.82-6.76 (m, lH); MS (m/z) $354\left(\mathrm{M}^{+}, 39\right), 78(100)$. Anal. Calcd for $\mathrm{C}_{20} \mathrm{H}_{14} \mathrm{~N}_{6} \mathrm{O}: \mathrm{C}, 67.79 ; \mathrm{H}, 3.98 ; \mathrm{N}, 23.72$. Found: $\mathrm{C}, 67.52 ; \mathrm{H}, 3.82 ; \mathrm{N}, 23.46$

7f. To a suspension containing $8 \mathrm{a}(0.48 \mathrm{~g}, 1 \mathrm{mmol})$ in acetonitrile $(10 \mathrm{~mL})$ anhydrous $\mathrm{K}_{2} \mathrm{CO}_{3}(0.55 \mathrm{~g}$, $4 \mathrm{mmol}$ ) was added. The general procedure then gave $0.26 \mathrm{~g}(75 \%)$ of $7 \mathrm{f}$ as orange needles: $\mathrm{mp} 304-305^{\circ} \mathrm{C}$ (EtOH); IR (KBr) 1703, 1619, 1541, 1447, 1413, 1281, 1235, 1192, $1163 \mathrm{~cm}^{-1}$; 'H NMR (DMSO-d $\left.{ }_{6}\right) \delta 11.44$ $(\mathrm{s}, 1 \mathrm{H}), 9.27(\mathrm{~d}, 1 \mathrm{H}, J=6.6 \mathrm{~Hz}), 8.34(\mathrm{dd}, 1 \mathrm{H}, J=8.1,1.8 \mathrm{~Hz}), 8.13-8.07(\mathrm{~m}, 1 \mathrm{H}), 8.01-7.95(\mathrm{~m}, 1 \mathrm{H}), 7.55-7.16$ $(\mathrm{m}, 7 \mathrm{H}), 6.95-6.89(\mathrm{~m}, 2 \mathrm{H})$; MS (m/z) $354\left(\mathrm{M}^{+}, 51\right), 235(15), 78(100)$. Anal. Calcd for $\mathrm{C}_{20} \mathrm{H}_{14} \mathrm{~N}_{6} \mathrm{O} .1 \mathrm{EtOH}$ : C, $65.99 ; H, 5.03 ;$ N, 20.99. Found: C, 66.30; H, $5.14 ;$ N, 20.98.

7g. From 2-amino-1-methyl-benzimidazole, following the general procedure, $7 \mathrm{~g}(0.32 \mathrm{~g}, 86 \%)$ was obtained as dark red needles: $\mathrm{mp} 237-238{ }^{\circ} \mathrm{C}$ (acetone); IR (KBr) 1704, 1607, 1578, 1440, $1181,1147 \mathrm{~cm}^{-1} ;{ }^{1} \mathrm{H}$ NMR (DMSO-d $\left.)_{6}\right) \delta 8.43(\mathrm{~d}, 1 \mathrm{H}, J=6.2 \mathrm{~Hz}), 8.22(\mathrm{dd}, 1 \mathrm{H}, J=7.7,1.8 \mathrm{~Hz}), 7.83-7.70(\mathrm{~m}, 2 \mathrm{H}), 7.67-7.60(\mathrm{~m}$, $2 \mathrm{H}), 7.36-7.23(\mathrm{~m}, 2 \mathrm{H}), 7.14-7.08(\mathrm{~m}, 2 \mathrm{H}), 6.94-6.90(\mathrm{~m}, 2 \mathrm{H}), 6.83-6.76(\mathrm{~m}, 1 \mathrm{H}), 3.78(\mathrm{~s}, 3 \mathrm{H}) . \mathrm{MS}(\mathrm{m} / \mathrm{z}) 368$ $\left(\mathrm{M}^{+}, 11\right), 221$ (5), $118(13), 78(100)$. Anal. Calcd for $\mathrm{C}_{21} \mathrm{H}_{16} \mathrm{~N}_{6} \mathrm{O}: \mathrm{C}, 68.45 ; \mathrm{H}, 4.38 ; \mathrm{N}, 22.81$. Found: $\mathrm{C}, 68.37$; $H, 4.03 ; N, 22.98$

\section{Synthesis of the Dimers 10 and 11.}

10. Following the general procedure, anhydrous $\mathrm{K}_{2} \mathrm{CO}_{3}(8 \mathrm{mmol})$ was added to 6 and 2-aminoimidazole hydrogen sulphate $(0.39 \mathrm{~g}, 1.5 \mathrm{mmol})$ and the mixture was stirred at room temperature for $48 \mathrm{~h}$ under argon. The mixture was filtered to provide 10 as dark red prisms $(0.33 \mathrm{~g}, 43 \%)$ : $\mathrm{mp} 284-285^{\circ} \mathrm{C}\left(\mathrm{CH}_{3} \mathrm{CN}\right)$; $\mathrm{IR}(\mathrm{KBr})$ 1702, 1623, 1548, 1446, 1299, 1266, $1198 \mathrm{~cm}^{-1}$; ${ }^{1} \mathrm{H}$ NMR (DMSO-d $) \delta 11.82(\mathrm{~s}, 1 \mathrm{H}), 9.25(\mathrm{~d}, 1 \mathrm{H}, J=6.6 \mathrm{~Hz}$ ), $8.36(\mathrm{dd}, 1 \mathrm{H}, J=7.9,1.7 \mathrm{~Hz}), 8.16-8.10(\mathrm{~m}, 1 \mathrm{H}), 8.04(\mathrm{t}, 1 \mathrm{H}, J=7.9 \mathrm{~Hz}), 7.54-7.40(\mathrm{~m}, 3 \mathrm{H}), 7.30(\mathrm{~d}, 2 \mathrm{H}, J$ $=7.7 \mathrm{~Hz}), 6.82(\mathrm{~s}, 2 \mathrm{H})$. Anal. Calcd for $\mathrm{C}_{32} \mathrm{H}_{25} \mathrm{IN}_{12} \mathrm{O}_{2} \cdot \mathrm{CH}_{3} \mathrm{CN}: \mathrm{C}, 52.52 ; \mathrm{H}, 3.63 ; \mathrm{N}, 23.42$. Found: $\mathrm{C}, 52.43$; H. $3.62 ; \mathrm{N}, 23.31$

11. A suspension containing $8 \mathrm{~b}(0,51 \mathrm{~g}, 1 \mathrm{mmol})$ and anhydrous $\mathrm{K}_{2} \mathrm{CO}_{3}(0.55 \mathrm{~g}, 4 \mathrm{mmol})$ in acetonitrile ( $10 \mathrm{~mL}$ ) was submitted to the general procedure, and after the usual work-up gave $0.31 \mathrm{~g}$ of $11(70 \%)$ as brown needles: $\mathrm{mp} 262-263{ }^{\circ} \mathrm{C}\left(\mathrm{CH}_{2} \mathrm{Cl}_{2}\right)$; IR (KBr) 2919, 2851, 1697, 1628, 1558, 1446, 1418, 1300, 1214, $1195 \mathrm{~cm}^{-1}$; ${ }^{\mathrm{H}} \mathrm{H}$ NMR (DMSO-d $\left.)_{6}\right) 11.24(\mathrm{~s}, 1 \mathrm{H}), 9.24(\mathrm{~d}, 1 \mathrm{H}, J=6.2 \mathrm{~Hz}), 8.32(\mathrm{dd}, 1 \mathrm{H}, J=8.1,1.8 \mathrm{~Hz}), 8.11-8.05$ $(\mathrm{m}, 1 \mathrm{H}), 7.95(\mathrm{td}, 1 \mathrm{H}, J=7.7,1.1 \mathrm{~Hz}), 7.55-7.40(\mathrm{~m}, 3 \mathrm{H}), 7.33-7.29(\mathrm{~m}, 2 \mathrm{H}), 7.08-6.98(\mathrm{~m}, 2 \mathrm{H}), 2.22(\mathrm{~s}, 6 \mathrm{H})$ Anal. Calcd for $\mathrm{C}_{44} \mathrm{H}_{37} \mathrm{IN}_{12} \mathrm{O}_{2}: \mathrm{C}, 59.20 ; \mathrm{H}, 4.18 ; \mathrm{N}, 18.83$. Found: $\mathrm{C}, 59.35 ; \mathrm{H}, 4.35 ; \mathrm{N}, 18.84$

\section{Synthesis of 2-(Benzimidazole-2-ylidenamino)-4-oxo-3-phenylpyrido[2,1- $f[1,2,4]$ triazinium Salts (8).}

8a. A suspension of $6(0.40 \mathrm{~g}, 1 \mathrm{mmol})$ and 2-aminobenzimidazole $(0.40 \mathrm{~g}, 3 \mathrm{mmol})$ in dry acetonitrile $(15 \mathrm{~mL})$ was stirred for $20 \mathrm{~h}$ at room temperature. The reaction mixture was filtered to furnish $8 \mathbf{8}$ as yellow 
needles $(0.40 \mathrm{~g}, 83 \%): \mathrm{mp} 318-319^{\circ} \mathrm{C}(\mathrm{EtOH})$; IR (KBr) 1708, 1622, 1580, 1522, 1477, 1434, $1301,1270 \mathrm{~cm}^{-1}$; ${ }^{1} \mathrm{H}$ NMR (DMSO-d $\left.d_{6}\right) \delta 12.46(\mathrm{~s}, 2 \mathrm{H}), 9.58-9.55(\mathrm{~m}, \mathrm{lH}), 8.61-8.57(\mathrm{~m}, \mathrm{lH}), 8.42-8.36(\mathrm{~m}, 2 \mathrm{H}), 7.61-7.35(\mathrm{~m}$, $7 \mathrm{H}), 7.30-7.24(\mathrm{~m}, 2 \mathrm{H})$. MS (m/z) $354\left(\mathrm{M}^{+}, 15\right), 235(9), 128(94)$. Anal. Calcd for $\mathrm{C}_{20} \mathrm{H}_{15} \mathrm{IN}_{6} \mathrm{O}: \mathrm{C}, 49.81, \mathrm{H}$, $3.13 ; \mathrm{N}, 17.42$. Found: $\mathrm{C}, 49.60 ; \mathrm{H}, 3.02 ; \mathrm{N}, 17.13$.

8b. A suspension of $6(0.40 \mathrm{~g}, 1 \mathrm{mmol})$ and 2-amino-5,6-dimethylbenzimidazole $(0.48 \mathrm{~g}, 3 \mathrm{mmol})$ in acetonitrile $(10 \mathrm{~mL})$ was stirred at room temperature for $48 \mathrm{~h}$. The solvent was removed to dryness and the residue was triturated with ethanol $(3 \mathrm{x} / \mathrm{mL})$. The solid formed was collected and crystallized, yielding $\mathbf{8 b}(0.4 \mathrm{l}$

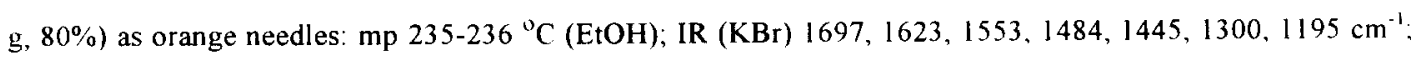
'H NMR (DMSO- $\left.d_{6}\right) \delta 12.15(\mathrm{~s}, 1 \mathrm{H}), 9.48(\mathrm{~d}, 1 \mathrm{H}, J=5.9 \mathrm{~Hz}) .8 .52(\mathrm{dd}, 1 \mathrm{H}, J=7.3,2.2 \mathrm{~Hz}), 8.33-8.27(\mathrm{~m}$, $2 \mathrm{H}), 7.58-7.33(\mathrm{~m}, 5 \mathrm{H}), 7.15(\mathrm{~s}, 2 \mathrm{H}), 2.26(\mathrm{~s}, 6 \mathrm{H})$. Anal Calcd for $\mathrm{C}_{22} \mathrm{H}_{19} \mathrm{IN}_{6} \mathrm{O}: \mathrm{C}, 51.78 ; \mathrm{H}, 3.75 ; \mathrm{N}, 16.47$. Found: C, $51.50 ; \mathrm{H}, 4.10 ; \mathrm{N}, 1616$

9. Method A. To a suspension of $7 f(0.35 \mathrm{~g}, 1 \mathrm{mmol})$ in EtOAc $(5 \mathrm{~mL})$, methyl iodide $(0.5 \mathrm{~mL}, 8 \mathrm{mmol})$ was added. The mixture was stirred for $24 \mathrm{~h}$ at room temperature and the precipitate was isolated by filtration yrelding $9(0.42 \mathrm{~g}, 87 \%)$ as yellow needles.

9. Method B. To a suspension of $0.37 \mathrm{~g}(1 \mathrm{mmol})$ of the heterobetaine $7 \mathbf{g}$ in methanol $(10 \mathrm{~mL}), 0.13 \mathrm{~mL}$ of $57 \% \mathrm{HI}$ were added dropwise after cooling to $0^{\circ} \mathrm{C}$. The mixture was then stirred for 5 min. Filtration provided 9 as yellow needles $(0.45 \mathrm{~g}, 91 \%): \mathrm{mp} 332-333^{\circ} \mathrm{C}(\mathrm{EtOH}) ; \mathrm{IR}(\mathrm{KBr}) 1708,1625,1583,1537,1482$. 1453, $1306 \mathrm{~cm}^{-1}$; 'H NMR (DMSO- $\left.d_{6}\right) \delta 12.30(\mathrm{~s}, 1 \mathrm{H}), 9.55-9.51(\mathrm{~m}, 1 \mathrm{H}), 8.65-8.60(\mathrm{~m}, 1 \mathrm{H}), 8.43-8.38(\mathrm{~m}$. $2 \mathrm{H}), 7.61-7.28(\mathrm{~m}, 9 \mathrm{H}), 3.20(\mathrm{~s}, 3 \mathrm{H})$. Anal Calcd for $\mathrm{C}_{21} \mathrm{H}_{17} \mathrm{IN}_{6} \mathrm{O}: \mathrm{C}, 50.82: \mathrm{H}, 3.45 ; \mathrm{N}, 16.93$. Found: C, 51.03 ; H, 3.27, N, 16.77 .

Single-Crystal X-Ray Structure Determination of Compounds 7f, 8a and 10. Intensity data were collected using a CAD4 diffractometer with graphite-monochromated MoK $\alpha$ radiation (0.71073 $\AA$ ). Data were collected at room temperature. Intensities were corrected for Lorenz and polarization effects in the usual manner. No absorption or extinction corrections were made.

The structures were solved by direct methods using SHELX $-86^{8}$ and refined by full matrix least-square analysis on $\mathrm{F}^{2}$ with SHELXL-93 9 . Non hydrogen atoms were anisotropically refined. When the quality of data allowed, hydrogen atoms were found by Fourier difference synthesis and refined isotropically, but in most cases hydrogen atoms where introduced from geometrical calculations in the last cycle of refinement with fixed thermal parameters. The solution of the structure for the dimeric compound indicated the iodide anion to exist in two different positions with occupancies of $90 \% \mathrm{I}(\mathrm{I})$ and $10 \% \mathrm{I}\left(1^{\prime}\right)$.

\section{ACKNOWLEDGMENTS}

We wish to express our thanks to the Comisió Interdepartamental de Reçerca i Innovació Tecnologica (CIRIT) for financial support (Project QFN94-4619) and to the Ministerio de Educación y Ciencia for a grant to one of us (JVM) 


\section{REFERENCES}

1. Ollis, W. D.; Stanforth, S. P. Tetrahedron 1985, 4l, 714

2. (a) Padwa, A in 1,3-Dipolar Cycloaddition Chemistry, Vol. 2, General Heterocyclic Chemistry Series, ed. Taylor, E.C.; Weissberger, A.; J.Wiley \& Sons, N.Y. 1984. (b) Boekelheide, V.; Fedoruk, N. A.; J. Org. (hem. 1968, 33, 2062.

3. For examples see: (a) Westphal, O.; Jahn, K.; Heffe, W. E. Arch. Pharm. 1961, 294, 37. (b) Matia, M. P.; Garcia, J. L.; Vaquero, J. J.; Alvarez-Builla, J. J. Heterocyclic (hem. 1990, 27, 661. (c) Matia, M. P.; Ezquerra, J.; Sanchez-Ferrando, F.; Garcia, J. L.; Vaquero, J. J.; Alvarez-Builla, J. Tetrahedron 1991, 47, 7329. (d) Matia, M. P.; Ezquerra, J.; Sanchez-Ferrando, F.; Garcia, J. L.; Vaquero, J. J.; AlvarezBuilla, J. Tetrahedron Lett. 1991, 32, 7575. (e) Hajós, G.; Messmer, A.; Bátori, S.; Riedl, Z. Bull. Soc. Chem. Belg. 1992, 101, 597. (f) Hajós, G.; Riedl, Z; Gács-Baitz, E.; Messmer, A. Tetrahedron 1992, 48, 8459. (g) Matia, M. P.; Garcia, J. L.; Vaquero, J. J; Alvarez-Builla, J. Liebigs Ann. (.hem. 1992, 777 (h) Santiesteban, I.; Siro, J. G.; Vaquero, J. J.; Garcia-Navio, J. L.; Alvarez-Builla, J.; Castaño. O J. Org. Chem. 1995, 60, 5667. (i) Diaz, A.; Matia, M. P.; Garcia, J. L.; Vaquero, J. J.; Alvarez-Builla, J. . J. Org. Chem. 1995, 59, 8294.

4. For examples see: (a) Bátori, S.: Juhász-Riedl, Zs.; Sandor, P.; Messmer, A. J. Heterocyclic (hem. 1986, 23, 375. (b) Bátori, S.; Messmer, A. J. Heterocyclic Chem. 1988, 25, 437. (c) Batori, S.; Hajós, G.; Sándor, P.; Messmer, A. J. Org. Chem. 1989, 54, 3062. (d) Bátori, S.; Messmer, A. J. Heterocyclic (hem. 1990, 27, 1673

5. (a) Cuadro, A. M.; Valenciano, J.; Vaquero, J. J.; Garcia, J. L.; Alvarez-Builla. J. Tetrahedmn 1993, 49, 3185. (b) Kakehi, A.; Ito, S.; Uchiyama, K.; Konno, Y; Kondo, K. J. Org. Chem. 1977, 42, 443.

6. (a) Alcalde, E. in $A d v$. Heterocycl. Chem. 1995, 60, 198 and references therein. (b) Alcalde, E.; Gisbert, M.: Pérez-Garcia, L. Tetrahedron 1995, 5I, 13365.

7. (a) de Pablo, M. S.; Gandásegui, T.; Vaquero, J. J.; Garcia-Navio, J. L.; Alvarez-Builla, J. Tetrahedron 1992, 48, 8793. (b) Newton, C. G.; Ollis, W. D.; Wright, D. J. Chem. Soc.. Perkin Trans. I. 1984, 69

8. Sheldrick, G.M. Acta Cryst. A 1990, 46, 467.

9. Sheldrick, G.M. SHELXL-93, University of Göttingen, 1993

(Received in UK 17 June 1996; revised 8 July 1996; accepted 11 July 1996) 